JOURNAL OF ENGINEERING SCIENCES

ЖУРНАЛ ІНЖЕНЕРНИХ НАУК

ЖУРНАЛ ИНЖЕНЕРНЫХ НАУК

Web site: http://jes.sumdu.edu.ua

DOI: $10.21272 /$ jes.2018.5(1).b1

Volume 5, Issue 1 (2018)

UDC 658.5+005.6+006

\title{
How to Assess the Performance Quality of an Enterprise
}

Kovalev A. I.

PJSC “Khmelnytskoblenergo”, 11a Khranovskogo St., 29016, Khmelnytskyi, Ukraine

Article info:

Paper received:

The final version of the paper received:

Paper accepted online:
September 30, 2017

January 14,2018

January 18, 2018
*Corresponding Author's Address:

polyfitt@gmail.com

\begin{abstract}
Proper assessment of enterprise performance quality expands opportunities of those enterprises proven by reputation, and creates favourable environment for investment. However, scientific literature does not present any research of enterprises' performance or functioning quality models from the perspective of all possible results. The article defines, in accordance with the requirements of the international management system standards, functioning efficiency - that is, resources turning into immediate results, immediate results transforming into direct ultimate results; sustained success - direct ultimate results turning into indirect ultimate results. Indirect ultimate results highlight strategic effect of an enterprise's sustained success. Ways of assessing functioning quality are classified, on the basis of which a system of information and analysis for collecting and processing of management information is developed for automation of assessment procedure.
\end{abstract}

Keywords: efficiency, sustained success, activity, functioning, automation.

\section{Introduction}

Quality assessment is a special type of the control function aimed at the formation of value judgments about the enterprise as an evaluated object. In accordance with ISO 9000:2015, quality is an independent characteristic of the object's essence for which a level (degree) of the required quality is existed. This level is assessed in relationship to the quality standard. This definition of quality makes it possible to provide a quantity assessment by the degree of compliance.

Quality appears "outside" through its properties. The property is an external demonstration of quality as the inner essence of the object [1]. A characteristic is the distinguishing feature, which can be own or assigned, qualitative or quantitative. The characteristic of quality is own characteristics of the enterprise arising from the requirements. The state of an enterprise is a set of characteristics that it possesses at the operating moment. Each characteristic has its assessment and can be determined.

The determination of quantitative characteristics of the quality of the work of enterprises is metrology, while not joint these characteristics with the justification of management decisions, as is customary in qualimetry. In qualimetry, the property (attribute) is the quality of the evaluation of measured object; value is the quantitative characteristic of a measure. An indicator is the numerical value of a measure by which one can indicate the state, change or development of the enterprise's processes. In the broadest sense of the word, an indicator is the trans- mitter of information. In the narrow sense, indicators are those characteristics that connect the object and the subject of evaluation [2]. The term "indicator" is also defined as a quantitative characteristic of one or several properties of objects considered under certain parameters [3]. In this case, the terms "indicator" and "parameter" are different. The parameter characterizes the state of an enterprise and its structure, but the indicator characterizes properties. Hence, the parameter is a relatively constant characteristic, which changes only when the enterprise changes itself. Parameters indicate how the enterprise differs from others. Thus, we will consider as indicators variables describing the properties reflecting the target, and parameters - the characteristics of the state, reflecting the quality of the functioning of the enterprise. International process-oriented management standards suggest the following parameters: efficiency, effectiveness, sustained success. Wherein, functioning is the behavior of the enterprise in time, the successive change of its state. At the same time, activity includes a system of processes carried out by an enterprise for the purpose of producing products, providing services or supporting them.

In order to express the state, it is necessary to determine the values accepted by the parameters at the considered moment, namely the values of efficiency, effectiveness, and sustainable success. The nomenclature of indicators evaluated in determining the properties and state of the enterprise should adequately reflect the actual level of parameters. Therefore, the choice of indicators is based on the study and modeling of the properties and condi- 
tions of the enterprise. Establishing the range of indicators is not a one-time, even if operation justified by scientific methods, but the process of constant adjustment. It depends on the enterprise development strategy [4].

Requirements of the standard ISO 9001:2015 concern the measurement of processes both for assessing the level of their effectiveness, and for maintaining in the managed state. In the first case, the results of the process are evaluated. In the second one, the indicators of its state at different stages are determined. The system of process quality indicators is divided into two groups. The first includes the implementation of the outputs of the process, and the second one - the characteristics of the dynamics of the process [5]. The first group of indicators fixes where the process comes as a result of control, and the second one how it gets to the final state. Thus, it is necessary to consider both indicators of quality of activity, and indicators of quality of functioning of the enterprise. The need to assess a sustained success also requires consideration and operationalization of concepts as a final results of the enterprise's activities, as well as the quality of functioning. Operationalization consists in the fact that investigated concepts are determined through the description of special measuring operations.

The purpose of this article is to analyze the models of the quality of activity and the functioning (A\&F) of the enterprise under the point of view of all possible outcomes and the development of operational definitions of these results in the context of requirements and recommendations of the standards ISO 9000.

\section{Research Methodology}

Quality assessment A\&F is the formation of value judgments about the enterprise, including an assessment of its properties and states using a set of indicators defined for each of the aspects (directions) of activity, e.g., resources, infrastructure, internal processes, financials, consumers, potential, and development.

The evaluation of the performance of activities is carried out based on direct results as a cost saving in obtaining these results. Evaluation of performance and sustainable success is carried out on the basis of final results (Fig. 1). Immediate results are what we have done, and the outcomes are what happened. Consequently, effectiveness is a characteristic of immediate results, productivity is a characteristic of direct outcomes, sustained success is a characteristic of indirect outcomes. In contrast to the traditional social notion of influence, it established as a strategic effect, correlated with indirect outcomes - quality of operation management, and estimated with the help of assessments of sustainable success in the long term.

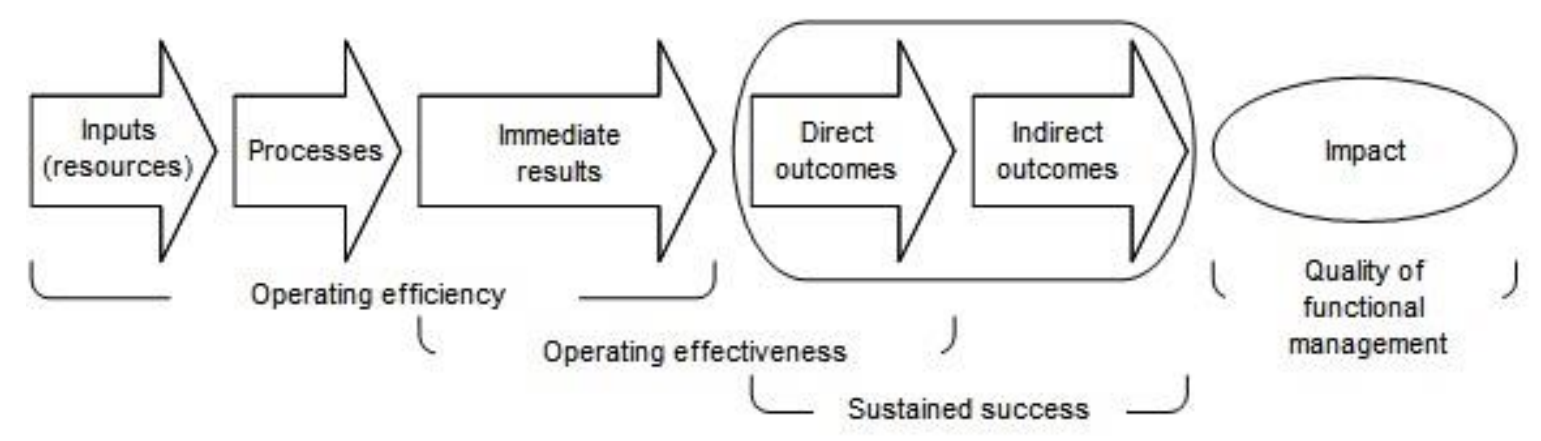

Figure 1 - The relationship between efficiency, effectiveness, sustained success and the quality of management in terms of immediate and final results

Figure 2 shows a diagram describing the company's A\&F hierarchy. It includes the company's embedded resources, processes, immediate results (produced goods and services), as well as final results and impact (strategic effect).

Immediate results should be presented in vector form

$$
x=\left(x^{(1)}, x^{(2)}, \ldots, x^{(n)}\right)^{T},
$$

where $x^{(j)}$-indicators characterizing various properties of the enterprise.
The final results should be presented as a complex indicator. Steady success is as a forecast, through the evaluation of the sequence of complex indicators. The effectiveness of the activity is determined by the evaluation of the resources spent on achieving the multivariate indicator (1). Alternatively, this indicator should contain private resource indicators, for example, as it is provided in the popular balanced scorecard including various aspects of the enterprise, resource and financial [6]. 


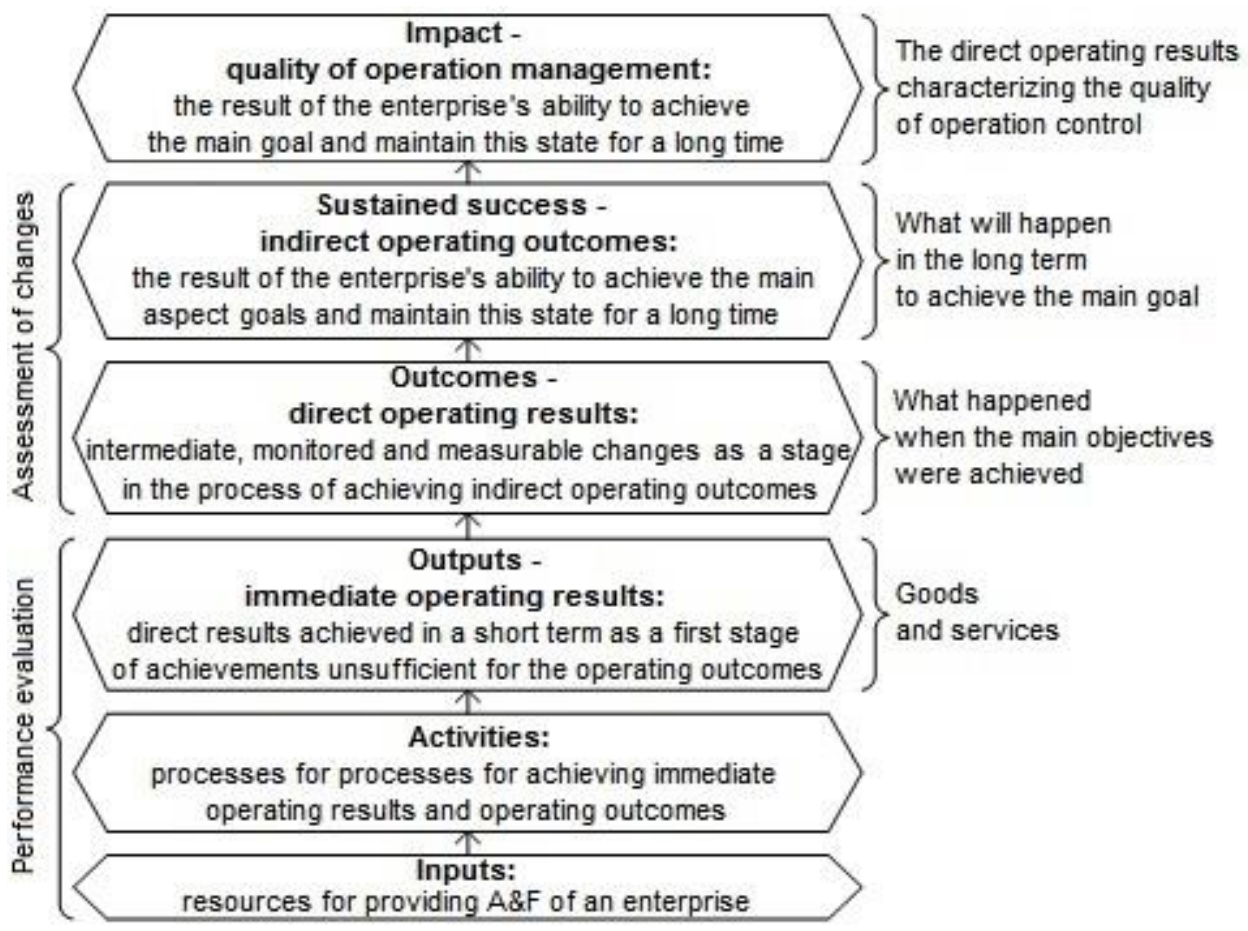

Figure 2 - A flowchart of the hierarchical presentation of the enterprise's operation

To identify possible ways of assessing the quality of A \& F, providing for appropriate decision-making procedures, consider the following. For any object of evaluation (the state of the enterprise), the set of its estimates for all indicators is a vector. It contains complete information about the object. If the estimated objects are comparable in the sense of domination, one can specify by binary relations in the space of estimations of indicators that determine the selection rule for each pair of objects of the best:

$$
\left(e_{r} \succ e_{k}\right) \Leftrightarrow\left(\begin{array}{l}
\forall j=\overline{1, n}: x_{r}^{(j)} \geq x_{k}^{(j)} ; r, k \in(1, \ldots, m) ; \\
\exists h \in(1, \ldots, n): x_{r}^{(h)}>x_{k}^{(h)}
\end{array}\right) .
$$

Substantially, this means that the object $e_{r}$ no worse than the object $e_{k}$ on any of the main aspect indicators, and, at least, one of them $e_{r}$ is better than $e_{k}$. Firstly, the evaluated objects will be compared by the indicators of the most important aspect, then - by the indications of the next important aspect, etc.

If the objects of evaluation are incomparable with the private aspect indicators of all aspects of activity, it is advisable to resort to the scalarization of the aspect indicators by building the complex indicators of aspects (CIA). When constructing a CIA, it is advisable to compare by advantage only homogeneous indicators that measure the intensity of properties of the same nature. To do this, the normalizing functions for the transformation $x^{(j)} \Rightarrow y^{(j)} \in[0,1]$ is used

As CIA a weighted sum of indicators is applied, which for $s$-th aspect of $i$-th object of evaluation has the following form:

$$
z_{i}^{(s)}=\sum_{j=1}^{n_{s}} w_{s} y_{i}^{(j)}, i \in(\overline{1, m})
$$

where $n_{s}$ - number of indicators of $s$-th aspect; $y_{i}^{(j)}-$ normalized value of $j$-th indicator for $i$-th object; $w_{s}$ - weights of partial indicators for $s$-th aspect of activity. The decisive rule has the following form:

$$
\left(e_{r} \succ e_{k}\right) \Leftrightarrow\left(\begin{array}{c}
\forall s: z_{r}^{(s)} \geq z_{k}^{(s)} ; r, k \in(\overline{1, m}) ; \\
\exists h \in(1,2, \ldots, s): z_{r}^{(h)}>z_{k}^{(h)}
\end{array}\right) .
$$

This means that $e_{r}$ object is no worse than $e_{k}$ for any of CIA and at least one of CIA $e_{r}$ is better than $e_{k}$.

1. The basis of the application of the method is the assumption of the independence of the influence of the value of each individual indicator $x_{i}^{(j)}$ or $z_{i}^{(j)}$ on the estimation of the preference of the object $e_{i}$ as a whole. In practice, this assumption is often not satisfied. In addition, the objects of estimation may not be comparable in the sense of the componentwise dominance of CIA, if each of the objects is preferable to the other for some particular indicator. It is possible to clarify the problem, to attract some additional assumptions that determine the method of estimation.

2. Additional assumptions may be related to a kind of binary relation as the lexicographic selection rule. It is used in the case of a ranking CIA according to the ranking of aspects of activity. Then, if the object $e_{r}$ is preferable to $e_{k}$ object by CIA of the most important aspect, then, independently of the CIA of other aspects of $e_{r}$, $e_{k}$ is preferable. If the objects are incomparable with CIA of the most important aspect, then they are compared according to CIA of the next most important aspect, and so on. 
3. Recognition of the enterprise's state is carried out using the data matrix $Y=\left\|y_{i}^{(j)}\right\|_{m}^{n}$.

Two classes of states $C_{g}, g=\{1,2\}$ are considered, where $C_{1}$ - values of indicators correspond to the annual planning assignments; $C_{2}-$ already achieved values of the indicators for the previous year. Distance measure $L_{g}\left(y, y_{g^{*}}\right)$ of the vector $y$ to reference vectors $y_{g^{*}}$ of these classes can be taken in the following form:

$$
L_{g}\left(y, y_{g *}\right)=\sum_{s=1}^{N} \sum_{j=1}^{n_{s}} w_{s}^{2}\left(y^{(j)}-y_{g *}^{(j)}\right)^{2},
$$

where $N$ - number of identified aspects of activity.

The decisive rule takes the form:

$$
y \in C_{g} \Leftrightarrow L_{g}=\min \left(L_{g}\right), g=\{1,2\} .
$$

4. An integral comparative evaluation characterizes the degree of similarity between two different enterprises. It can be presented by an integral measure - a linear distance $\delta_{r k}$ between column vectors $y_{r}^{(j)}$ and $y_{k}^{(j)}$ of of the transpose matrix $Y^{T}$

$$
\delta_{r k}=\sum_{s=1}^{N} \sum_{j=1}^{n_{s}} w_{s}^{2}\left(y_{r}^{(j)}-y_{k}^{(j)}\right)^{2}, \quad r, k=\overline{1, m},
$$

where $y_{r}^{(j)}, y_{k}^{(j)}$ - values of $j$-th indicator for $r$-th and $k$-th enterprises.

Columns of the matrices $Y^{T}$ correspond to enterprises, and rows - to theirs indicators. An element $\delta_{r k}$ is the measure of the difference between enterprises $r$ and $k$. The matrix $\Delta=\left\|\delta_{r k}\right\|_{m}^{m}$ specifies the dual relations "to be predominant" or "equal", or "to be no worse", because its components are measures of the difference between enterprises $r$ and $k$. Such information is interest when conclusions based on numerical indicators include ranking. Particularly, the purpose of a comparative study of enterprises is ranking by the data combination.

5 . in general, calculation of the global quality assessment of enterprise's A\&F consists in building the exponents of the scalar function $y_{i}{ }^{o}$ in the space of indicators, which relates each object to an estimate of its "generalized quality":

$$
y_{i}^{o}=\sum_{s=1}^{N} \sum_{j=1}^{n_{s}} w_{s}^{2}\left(y_{i}^{(j)}-y_{\max }^{(j)}\right)^{2}, i=\overline{1, m},
$$

where $y^{(j)}{ }_{\max }$ - components of the vector characterizing the enterprise, chosen as a reference for comparison.

For convenience of comparison for various variants of objects, estimation limiting values of indicators $y_{\max }$ should correspond to the initial state - the given (normative) values from the point of view of the long-term strategic objectives of the enterprise. To solve the forecasting problem, it is necessary to check periodically the selected set of indicators. Thus, complex factors $y_{i}{ }^{o}\left(t_{0}\right), y_{i}{ }^{o}\left(t_{1}\right), \ldots$ are obtained, the forecasting of which changes in sustainable success can be predicted.

To automate the evaluation procedure (including the abovementioned method), a block diagram of the algorithm for the corresponding information and analytical system (IAS) (Fig. 3). The technology of estimation based on the estimation methods given by formulas (2)-(7).

IAS is devoted to improve the efficiency and quality of management decisions by automating the information and analytical activities of the enterprise. The object of automation is the procedure for assessing the quality of enterprise's A\&F based on the balanced set of indicators (in terms of activities).

All the AIS data are located in the central repository and contain the following levels: collection and primary data processing; extracting, transforming and loading data; data storage; presentation in data marts; data analysis.

Data marts are organized in the form of multidimensional databases, where reference information is presented by indicators and output - by quality parameters of enterprise's A\&F summarizing these indicators. Information in a multidimensional data mart is presented in terms of business in the form most accessible to users, which allows significantly reducing time for obtaining information necessary for decision-making. The use of multidimensional data marts and corresponding program for data analysis allows transforming data into useful information based on which effective decisions are made. The program for data analysis is used to access to information, visualize it, as well for the multivariate analysis, form and compose reports. An input data for the analysis is the preprocessed data from the repository or presented in a data mart.

Part of the quality of enterprise's A\&F is the quality of management characterizing some ability of the enterprise. It is one of the types of competitiveness. In terms of process-oriented standards, the quality of management characterizes the steady success of an enterprise. 


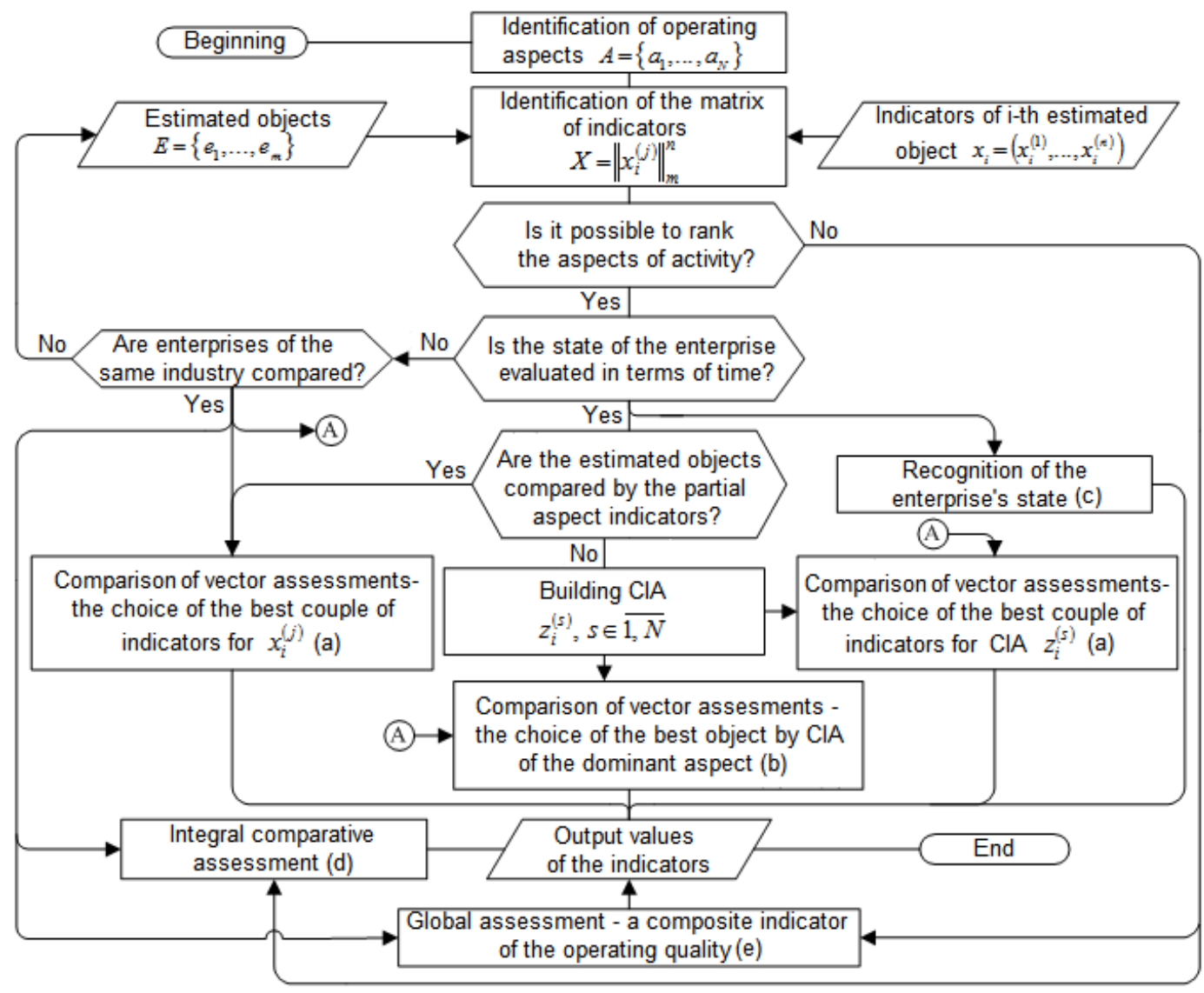

Figure 3 - A flowchart of algorithm of information-analytical system

Management of enterprises is realized by the implementation of interrelated management functions. The quality of management is characterized by a stable interaction of managerial functions, as well as a stable interaction of processes is a characteristic of the quality of operating activities (the transformation of materials and information into a final product and delivery of the product to the consumer). Therefore, management functions should be identified for each enterprise. This fact does not exclude their repeatability, especially in the industry context. At the level of the interrelationships of functions, the differentiation of enterprises should be more significant, because the differentiation is a field of competitive advantages that distinguishes one enterprise from another one. Innovative sustainable relationships of established management functions are the part of intangible assets as an area for creating competitive advantages.

The quality of management is the subject of enterprise strategy, and the criterion of good governance is successful implementation of the strategy. If suppose that an enterprise firstly proposes the quality management functions within the standard ISO 9000: 2015 (quality planning, assurance, control and improvement), then to implement the strategy it can concentrate efforts on detailed quality planning, neglecting, and control: there are goals, tasks, resources. So, the fulfillment of quality requirements is delegated to units. There is another situation where documentation and close monitoring are carried out, particularly statistical control of operating activities. Perhaps, priorities to ensure consumer loyalty, create a brand will be chosen, or the path for resource investments and improvements will be proposed (e.g. new developments and technological innovations). Knowing the capabilities of the enterprise and identified strategies determine the ways to achieve success. If success is achieved, the quality of management is high. If the success is unsufficient, then with the unchanged profile of organizational capabilities and the chosen strategy, the enterprise can change the management functions, their resource supply, introduce new functions, and so on.

So, if control is carried out with the help of a set of interrelated functions, then the functions express an essential determinateness inherent in management, due to which the management is precisely such.. Thus, the quality of management is the degree of correspondence of the inherent characteristics (functions) of management to the established requirements. Particularly, this means that the identification of management functions should be based on the identified requirements of interested parties. The quality of management and the competitive advantage of the enterprise will consist in the extent to which the requirements and needs are investigated, as well as functions are adequately identified and implemented. A certain set of management functions of the enterprise for the market condirions is assessed in their relationships, which allows judging the quality of management as a whole.

Assessment of the quality of management can be approximately realized using the expert assessments based on a number of evaluation categories, if it is possible to correctly select experts and organize an evaluation procedure. The field of managerial quality is dynamic and individual as "know-how", until it becomes a common 
property. Enterprises can find and implement unique functions. How an enterprise works is a consequence of a combination of individual characteristics of its internal and external environments. Consequently, management functions can also be individual.

Finally, the quality of management reflects a stable relationship between the constituent elements of $A \& F$ (managerial functions) characterizing the specific management, which allows distinguish management approaches.

\section{Conclusions}

In this paper, ways for the determination of the enterprise's A\&F quality is proposed by the parameters of its condition: efficiency, effectiveness, and sustained success. The traditional presentation of operational results are immediate and final results, as well as the impact. The new approach is in the fact, that efficiency reflects the transition of resources and processes to immediate results, as well as effectiveness reflects the transition of direct results to outcomes, and sustained success reflects the transition of direct outcomes to indirect ones.

In contrast to the presentation of non-productive (noncommercial) impact of the final result (e.g., social), a strategic effect of the sustainable success of the enterprise is established. If a causal relationship is established be- tween the final (remote) results and the effect of sustained success, the outcomes are indirect evidences of it. The trend of a change in sustainable success can be assessed by periodic monitoring of the complex indicator of quality A\&F (7) including the identified set of the most informative indicators.

Methods for assessing the quality A\&F are defined and corresponding IAS is developed considering the proposed approach, which allows realizing new ways of informatization, and intellectualization of management processes.

The quality of management of functioning is defined as a characteristic of the effectiveness of functioning in the long term. In the standard ISO 9004:2012 it is called as a steady success. This approach is reliable, if it is assumed that enterprises fulfill the adopted restrictions when achieving the goals. However, it is better if the satisfaction of constraints (the achievement of efficiency) is included into the set of vector's indicators (1). If the enterprise uses such indicators (e.g., balanced containing resource (financial) components), the quality $\mathrm{A} \& \mathrm{~F}$ (direct results and outcomes) can characterized by joint assessments of efficiency and effectiveness. Additionally, the quality of performance management (indirect outcomes) is assessments of efficiency and effectiveness in a long term: Permanent monitoring of the complex indicator (7) provides a tool for predicting sustainable success.

\title{
References
}

1. Bondarevskiy, A. S. (2008). Axiomatics of informational operations accuracy. Fundamental research, No. 6, 11-25 [in Russian].

2. Guts, A. K., Korobitsin, V. V., Laptev, A. A., Pautova L. A., \& Frolova, J. V. (2000). Mathematical Models of Social Systems. Omsk State University Publ., Omsk, Russia.

3. Pershikov, V. I., \& Savinkov, V. M. (1991). The explanatory dictionary on informatics. Finansy i statistika Publ., Moscow, Russia [in Russian].

4. Konyukhov, A. G. (1990). Metrological support in instrument making. Management aspects. Izdatel'stvo standartov Publ., Moscow, Russia [in Russian].

5. Kovalev, A. I. (2009). Complex and dynamic processes of management. Standards and quality, No. 12, $72-73$ [in Russian].

6. Kaplan, R. S., \& Norton, D. P. (1996). The Balanced Scorecard: Translating Strategy into Action. Harvard Business Press Books, Boston, USA.

\section{Як оцінити якість роботи підприємства}

\author{
Ковальов О. І.
}

ПАТ «Хмельницькобленерго», вул. Храновського, 29016, м. Хмельницький, Україна

\begin{abstract}
Анотація. Адекватне оцінювання якості роботи підприємств розширює їх можливості, які підтверджуються репутацією, і створює сприятливі умови для залучення інвестицій. Однак у науковій літературі не представлені дослідження моделей якості діяльності та функціонування підприємств 3 точки зору всіх можливих результатів. У статті визначено відповідно до вимог міжнародних стандартів на системи управління ефективність діяльності, результативність функціонування, стійкий успіх підприємства і якість управління (стратегічний ефект сталого успіху) згідно логічної послідовності «ресурси - безпосередні результати - прямі і непрямі кінцеві результати». Представлена класифікація способів оцінювання якості діяльності / функціонування, на основі якої розроблена інформаційно-аналітична система збору та обробки управлінської інформації для автоматизації процедури оцінювання.
\end{abstract}

Ключові слова: ефективність, результативність, стійкий успіх, діяльність, функціонування, автоматизація. 